\section{A sampling of current Canadian Thoracic Society priorities}

\begin{abstract}
$A \mathrm{t}$ first glance, the workings of the Canadian Thoracic A society (CTS) may seem somewhat mysterious. There has been tremendous growth in the Society's activities and structure over the past decade, and the primary objective of the President's page is to give members a view into what is happening within the CTS and its Committees. The ultimate goal is to encourage members to participate in ongoing projects, as well as to encourage those with novel ideas to look to the CTS as a nimble and responsive organization that can help turn concepts into reality.
\end{abstract}

\section{CTS COMMITTEE STRUCTURE AND BOARD CONSTITUENCY}

The CTS Board is comprised of the CTS Executive (PastPresident, President, President-Elect, Treasurer, Secretary and CEO of the Canadian Lung Association) along with Chairs of standing and ad hoc committees. The Board meets twice per year, at an Annual Meeting held in the fall in association with the American College of Chest Physicians, as well as at an Annual Spring Board Meeting.

The full CTS Board is large and tends to be somewhat unwieldy, especially when the need arises to conduct discussion and to get feedback and consensus on issues in a short and responsive time frame. For this reason, the CTS Executive meets monthly by teleconference, as well as when needed to deal with issues arising.

But does the current CTS committee structure, which has evolved over decades, adequately reflect the interests and priorities of the CTS membership? It clearly makes sense to have committees that address broad areas of interest, such as research, education and professional development, standards, practice guidelines, etc. However, while there are diseasespecific committees focusing on asthma, chronic obstructive pulmonary disease, sleep disorders, tuberculosis and pulmonary vascular diseases, amazingly, we do not have committees that focus on such fundamental areas as cancer, pulmonary infections and diffuse lung diseases, to mention a few. Furthermore, differing committee objectives can result in inconsistency and inefficiency. For example, the learnings derived from the development of practice guidelines by one committee have not always been directly transferred to the guidelines work conducted by other committees. The CTS Respiratory Guidelines Committee was recently created to bridge this gap by developing protocols and procedures that can transcend the details of disease specifics.

To examine whether alternative organizational structures may better meet the needs of the respiratory community, a

\section{Quelques-unes des priorités actuelles de la Société canadienne de thoracologie}

\begin{abstract}
$A$ u premier coup d'œil, les travaux de la Société canadienne Ade thoracologie (SCT) peuvent sembler quelque peu mystérieux. Les activités et la structure de la Société ont connu une énorme croissance depuis dix ans, et le principal objectif de la page du président consiste à donner aux membres un aperçu de ce qui se passe au sein de la SCT et de ses comités. On vise ainsi à encourager les membres à participer aux projets en cours et à inciter ceux ayant des idées nouvelles à percevoir la SCT comme un organisme dynamique et éclairé qui peut contribuer à transformer les concepts en réalité.
\end{abstract}

\section{LA STRUCTURE DES COMITÉS DE LA SCT ET LA COMPOSITION DU CONSEIL}

Le conseil de la SCT se compose du comité directeur de la SCT (président sortant, président, président désigné, trésorier, secrétaire et chef de la direction de l'Association pulmonaire du Canada) et des présidents des comités permanents et ponctuels. Le conseil se rencontre deux fois l'an dans le cadre d'un congrès annuel, tenu à l'automne, conjointement avec l'American College of Chest Physicians, et d'une réunion annuelle du conseil au printemps.

Le conseil de la SCT est grand et a tendance à être complexe, surtout lorsqu'il faut mener des discussions et obtenir des commentaires et un consensus éclairés rapidement. C'est pourquoi le comité directeur de la SCT se rencontre tous les mois par téléconférence et au besoin pour traiter les questions qui surgissent.

La structure actuelle des comités de la SCT, qui a évolué au fil des décennies, reflète-t-elle convenablement les intérêts et les priorités des membres de la SCT ? De toute évidence, il est logique de disposer de comités qui se penchent sur de vastes sujets d'intérêt tels que la recherche, la formation et le perfectionnement professionnel, les normes, les guides de pratique, etc. Cependant, tandis que des comités axés sur des maladies s'intéressent à l'asthme, aux maladies pulmonaires obstructives chroniques, aux troubles du sommeil, à la tuberculose et aux maladies vasculaires pulmonaires, étonnamment, aucun comité ne s'intéresse à des secteurs aussi fondamentaux que le cancer, les infections pulmonaires et les maladies pulmonaires diffuses, pour n'en nommer que quelques-uns. De plus, les objectifs divergents des comités peuvent entraîner des incohérences et des résultats inefficaces. Par exemple, les apprentissages dérivés de l'élaboration de guides de pratique par un seul comité n'ont pas toujours été transférés directement dans les travaux relatifs aux lignes directrices d'autres comités. Le comité des lignes directrices sur la santé respiratoire de la SCT a récemment été mis sur pied 
preliminary meeting will be held in May, involving the CTS Executive and the Long Range Planning Committee (chaired by Dr Gerard Cox). The intent will be to review how other national societies of comparable size and mandate are organized, and to consider alternative organizational structures for the CTS. These preliminary ideas will be further developed for presentation to the entire CTS Board and for discussion at the CTS Annual Meeting in Philadelphia (Pennsylvania, USA) in October 2008.

\section{PARTNERSHIPS}

Much consideration is being given to strengthening partnerships between the CTS and a number of groups. Relations are at an all-time high with the Canadian Lung Association, with substantial progress being made jointly in a number of areas, most notably the current collaborative work being performed on the development of the Lung Health Framework.

Extensive discussions between the CTS and the Canadian pediatric respirologist community have taken place over the past two years. There have been concerns that the CTS Pediatric Respiratory Committee (whose Chair sits on the CTS Board) has not really met the full needs of this tight-knit group of predominantly academic specialists. Our pediatric colleagues have made a major commitment to increase their activity in partnership with (and within the structure of) the CTS under the leadership of Dr Tom Kovesi. The precise details of the working relationship are yet to be concisely defined as we revise the CTS Rules and Regulations. However, there is clearly a strong mutual interest to have the relationship continue to grow, with a prominent pediatric respiratory voice and perspective in all CTS activities.

The 'Canadian Respiratory Conference 2008: A Breath of Fresh Air' will take place in June in Montreal, Quebec, and judging by early registration numbers, it should be a tremendous success. Developmental work for this national showcase has fostered and strengthened working relationships between the CTS and its partners in the conference, the Canadian COPD Alliance, the Canadian Respiratory Health Professionals and the Canadian Lung Association. We have seen wonderful cooperation and collegiality, with major participation from all of the partners on the Organizing Committee and the Planning Committee. Looking down the road to future iterations of the Canadian Respiratory Conference, we will be actively seeking to expand our partnership umbrella to include other organizations, groups and societies (including thoracic surgeons, radiologists and pathologists, among others) with major interests in respiratory health, education and research.

\section{RESPIROLOGY MANPOWER IN CANADA}

A recent article (1) in the Canadian Medical Association Journal highlighted an increasing need for training and recruitment of new specialists in Canada. Interestingly, remarkably little information is available regarding manpower needs for many specialties. Furthermore, there is a lack of clarity as to who is responsible for collating this information in a systematic fashion. Is it the responsibility of the Royal College of Physicians and Surgeons of Canada, the Canadian Medical Association or specialty societies? pour combler cet écart par des protocoles et des marches à suivre qui peuvent transcender les détails propres aux caractéristiques des maladies.

Pour examiner si d'autres structures organisationnelles pourraient mieux respecter les besoins de la communauté de la santé respiratoire, une rencontre préliminaire aura lieu en mai avec le comité directeur de la SCT et le comité de planification à long terme (présidé par le docteur Gerard Cox). Elle permettra d'analyser l'organisation d'autres sociétés nationales à la dimension et au mandat comparables et d'envisager d'autres structures organisationnelles pour la SCT. Ces idées préliminaires seront élaborées davantage afin d'être présentées à l'ensemble du conseil de la SCT et d'en discuter au congrès annuel de la SCT à Philadelphie (Pennsylvanie, États-Unis) en octobre 2008.

\section{DES PARTENARIATS}

On réfléchit beaucoup au renforcement des partenariats entre la SCT et divers groupes. Les relations n'ont jamais été aussi harmonieuses avec l'Association pulmonaire du Canada, des progrès conjoints importants s'observant dans plusieurs domaines, notamment la collaboration pour créer le Cadre de travail sur la santé pulmonaire.

Des discussions approfondies entre la SCT et la communauté des pneumologues pédiatres du Canada se sont poursuivies depuis deux ans. On se demande si le comité de pneumologie pédiatrique de la SCT (dont le président siège au conseil de la SCT) a vraiment respecté tous les besoins de ce groupe compact composé surtout de spécialistes universitaires. Nos collègues pédiatres ont pris l'important engagement d'accroître leurs activités en partenariat avec (et dans le cadre de la structure de) la SCT, sous la direction du docteur Tom Kovesi. Le détail précis de la relation de travail reste à définir avec concision dans les règles et règlements de la SCT en cours de révision. Cependant, de toute évidence, il existe un solide intérêt mutuel à faire fructifier la relation, en apportant le point de vue et la perspective de la santé respiratoire pédiatrique à toutes les activités de la SCT.

Le « Congrès canadien sur la santé respiratoire 2008 : Une bouffée d'air frais » aura lieu en juin à Montréal, au Québec, et d'après les premiers résultats des préinscriptions, il devrait obtenir un succès retentissant. L'élaboration de cette vitrine nationale a suscité et renforcé les relations de travail entre la SCT et ses partenaires du congrès, l'Alliance canadienne sur la MPOC, les Professionnels canadiens en santé respiratoire et l'Association pulmonaire du Canada. Nous avons observé une merveilleuse collaboration et une grande collégialité de tous les partenaires du comité organisateur et du comité de planification. Lors des prochains congrès canadiens sur la santé respiratoire, nous chercherons activement à élargir nos partenariats pour inclure d'autres organismes, groupes et sociétés (y compris les chirurgiens thoraciques, les radiologues et les pathologistes, entre autres) ayant un intérêt marqué pour la santé respiratoire, la formation et la recherche.

\section{LES EFFECTIFS EN SANTÉ RESPIRATOIRE AU CANADA}

Un récent article (1) du Journal de l'Association médicale canadienne souligne le besoin croissant de formation et de 
The most recent formal attempt to generate accurate information regarding respiratory medicine manpower was a survey conducted and reported by Cockroft and Wensley (2) in 2000. The authors identified a serious shortfall in the number of adult and pediatric respirologists in Canada, and they cautioned that output from Canadian training programs in adult and pediatric respirology was not likely to meet this need. It is highly likely that the gap has expanded since that report. In view of the need for more accurate and up-to-date information for planning purposes, Dr Sat Sharma has agreed to lead an initiative on behalf of the CTS to ascertain the current manpower gap to help determine training and recruitment needs in Canada in the short-term and long-term time frames.

As always, if there are CTS initiatives that tweak your interest or if you have ideas waiting to be realized, your input and participation is enthusiastically encouraged!

Respectfully submitted,

Robert D Levy MD FRCPC President, Canadian Thoracic Society

\section{REFERENCES}

1. Howell E. Physician, count thyself. CMAJ 2008;178:381-4.

2. Cockcroft DW, Wensley D. Respirology manpower in Canada A report for the Canadian Thoracic Society Education Committee. Can Respir J 2000;7:451-5. recrutement de nouveaux spécialistes au Canada. Fait intéressant, il existe très peu d'information sur les besoins en effectifs dans de nombreuses spécialités. De plus, on ne sait pas exactement qui est responsable de recueillir l'information systématique. Est-ce le Collège royal des médecins et chirurgiens du Canada, l'Association médicale canadienne ou les sociétés de spécialité ?

La plus récente tentative officielle pour obtenir de l'information précises au sujet des effectifs en médecine respiratoire provient d'un sondage mené et colligé par Cockroft et Wensley (2) en 2000. Les auteurs ont constaté une grave pénurie de spécialiste en troubles respiratoires pour adultes et pour enfants au Canada, et ils ont indiqué que les diplômés des programmes de formations canadiens en pneumologie pour adultes et pour enfants n'étaient pas susceptibles de respecter ce besoin. Il est fort probable que l'écart se soit creusé depuis ce rapport. Étant donné la nécessité d'obtenir des données plus précises et plus à jour pour des besoins de planification, le docteur Sat Sharma a accepté de mener un projet pour le compte de la SCT afin d'évaluer la pénurie actuelle d'effectifs et de mieux déterminer les besoins de formation et de recrutement à court et à long terme au Canada.

Comme toujours, si des projets de la SCT éveillent votre intérêt ou si vous avez des idées qui attendent d'être réalisées, c'est avec enthousiasme que nous accueillerons votre apport et votre participation.

Amicalement,

Robert D Levy MD FRCPC Président, Société canadienne de thoracologie

\section{RÉFÉRENCES}

1. Howell E. Physician, count thyself. CMAJ 2008;178:381-4.

2. Cockcroft DW, Wensley D. Respirology manpower in Canada A report for the Canadian Thoracic Society Education Committee. Can Respir J 2000;7:451-5. 


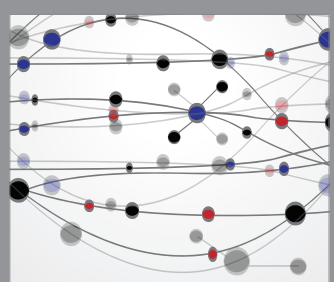

The Scientific World Journal
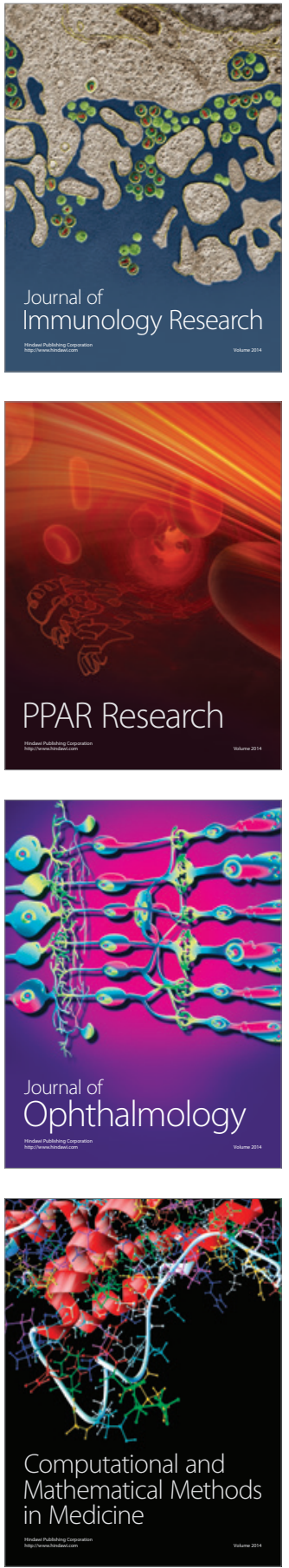

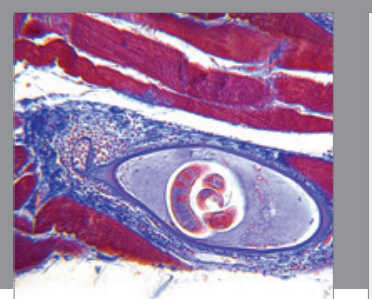

Gastroenterology Research and Practice

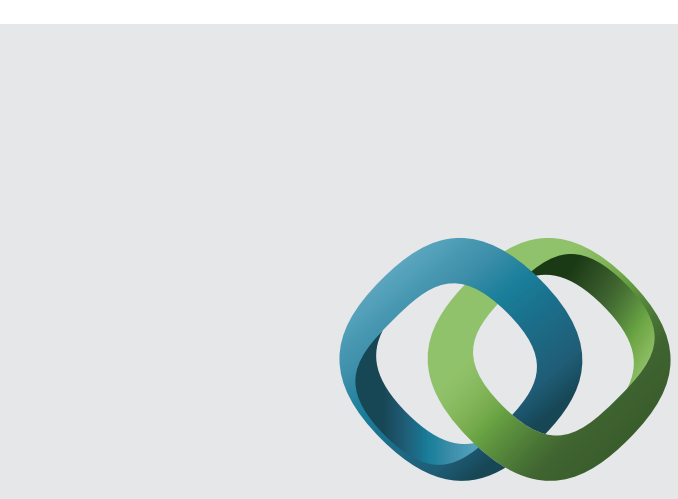

\section{Hindawi}

Submit your manuscripts at

http://www.hindawi.com
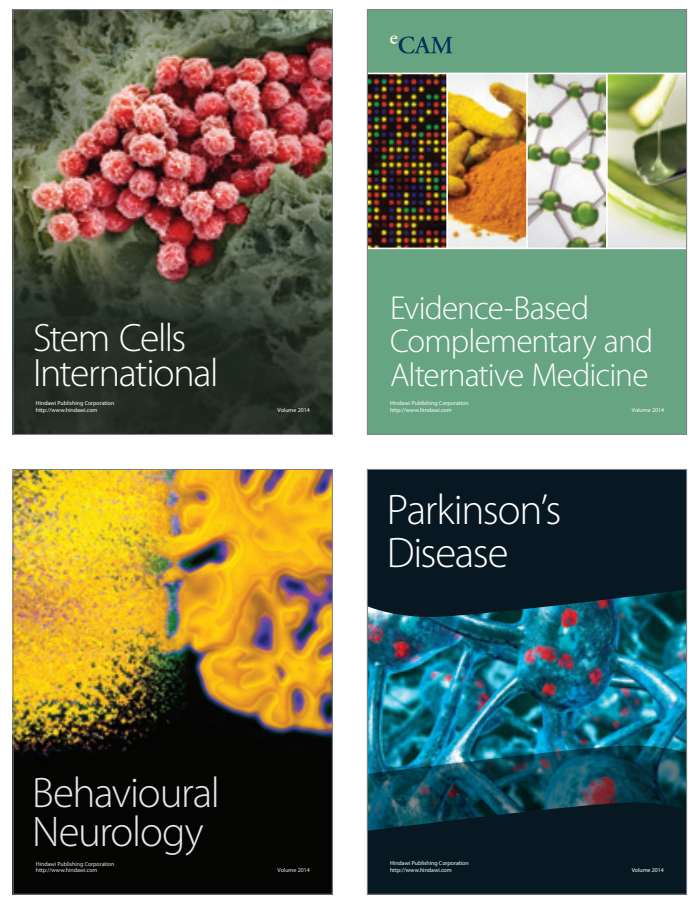
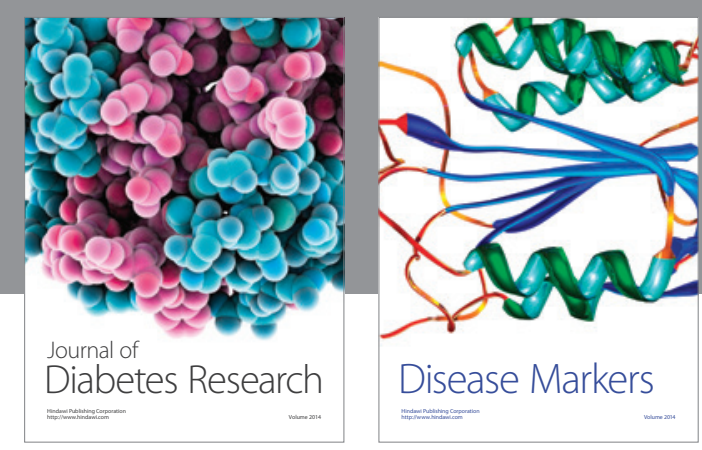

Disease Markers
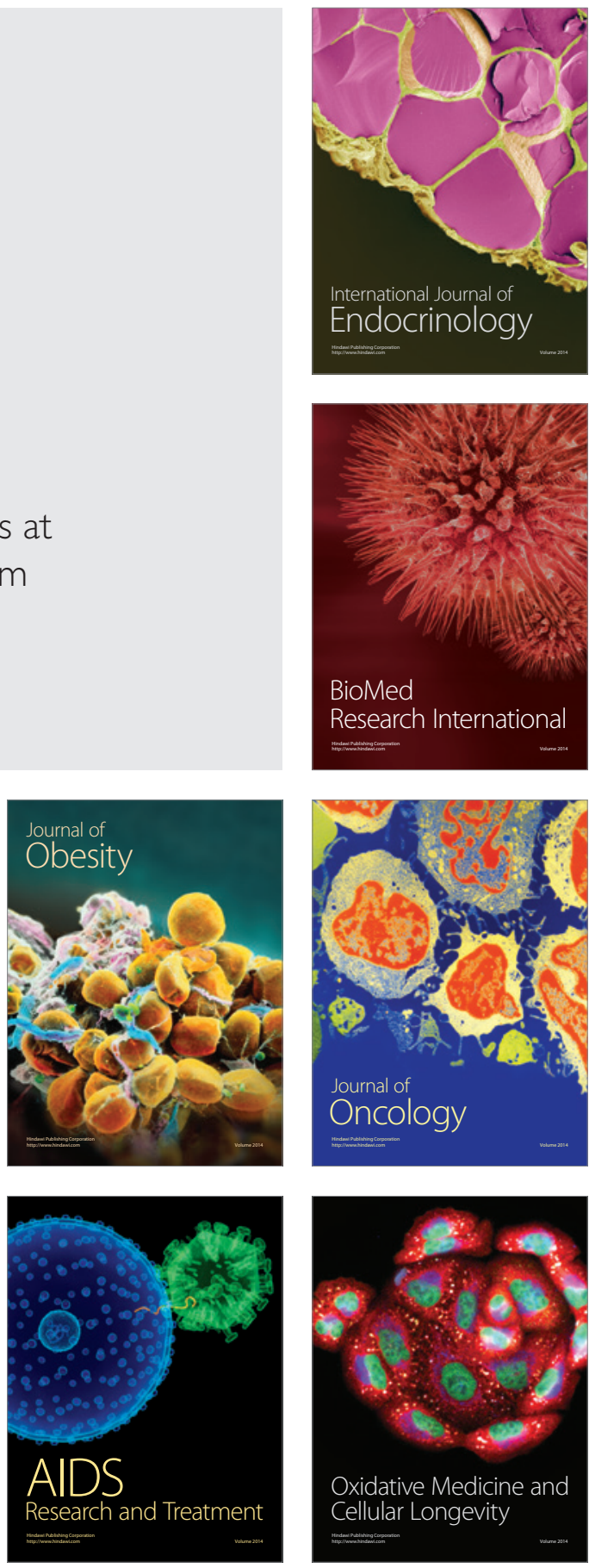